\title{
RESEARCH
}

Open Access

\section{Neolignans isolated from twigs of Nectandra leucantha Ness \& Mart (Lauraceae) displayed in vitro antileishmanial activity}

Simone S Grecco ${ }^{1,2}$, Thais A Costa-Silva ${ }^{1}$, Fernanda S Sousa ${ }^{3}$, Stefano B Cargnelutti ${ }^{3}$, Eric Umehara', Poliana S Mendonça' ${ }^{1}$, Andre G Tempone ${ }^{4}$ and Joao Henrique G Lago ${ }^{1 *}$

\begin{abstract}
Background: The therapeutic arsenal for the treatment of Leishmaniasis is limited and includes toxic compounds (antimonials, amphotericin B, pentamidine and miltefosine). Given these aspects, the search for new compounds based on floristic biodiversity is crucial. In the present work, we report the isolation, characterization and antileishmanial activity of six related neolignans (1-6) of bioactive extract from Nectandra leucantha (Lauraceae) twigs.

Methods: Dried and powdered twigs of $N$. leucantha were exhaustively extracted using $n$-hexane. The crude extract was dereplicated by HPLC/HRESIMS and subjected to column chromatography to yield pure compounds 1-6. Their chemical structures were identified via NMR and comparison of obtained data with those previously published in the literature. Biological assays of compounds 1-6 and their respective monomers (eugenol and methyleugenol) were performed using promastigote and amastigote forms of Leishmania (L.) infantum.

Results: Dereplication procedures followed by chemical characterization of isolated compounds by NMR enabled the identification of related neolignans 1-6. Neolignans 2, 4 and 6 showed potential against amastigote forms of $L$. (L.) infantum ( $\mathrm{EC}_{50}$ values of 57.9, 67.7 and $13.7 \mu \mathrm{M}$, respectively), while compounds 1 and 3 were inactive. As neolignans 2-4 are chemically related, it may be suggested that the presence of the methoxyl group at C4 constitutes an important structural aspect to increase antileishmanial potential against amastigote forms. Compound 6 , which consists of a methylated derivative of compound 5 (inactive) showed antileishmanial activity similar to that of the standard drug miltefosine $\left(E C_{50}=16.9 \mu \mathrm{M}\right)$ but with reduced toxicity $(S \mathrm{I}=14.6$ and 7.2, respectively). Finally, two related monomers, eugenol and methyleugenol, were also tested and did not display activity, suggesting that the formation of dimeric compounds by oxidative coupling is crucial for antiparasitic activity of dimeric compounds 2, 4 and 6 .
\end{abstract}

Conclusion: This study highlights compound 6 against L. (L.) infantum amastigotes as a scaffold for future design of new compounds for drug treatment of visceral leishmaniasis.

Keywords: Nectandra leucantha, Leishmania (L.) infantum, Antileishmanial activity, Neolignans

\footnotetext{
* Correspondence: joao.lago@ufabc.edu.br

${ }^{1}$ Center of Natural Sciences and Humanities, Federal University of ABC

(UFBC), Avenida dos Estados 5001, Santo Andre, SP 09210-580, Brazil

Full list of author information is available at the end of the article
}

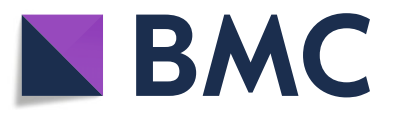

(c) The Author(s). 2018 Open Access This article is distributed under the terms of the Creative Commons Attribution 4.0 International License (http://creativecommons.org/licenses/by/4.0/), which permits unrestricted use, distribution, and reproduction in any medium, provided you give appropriate credit to the original author(s) and the source, provide a link to the Creative Commons license, and indicate if changes were made. The Creative Commons Public Domain Dedication waiver (http://creativecommons.org/publicdomain/zero/1.0/) applies to the data made available in this article, unless otherwise stated. 


\section{Background}

Leishmaniasis is a neglected tropical disease (NTD) that affects more than one billion people in tropical and subtropical countries, including parts of Latin America, Africa and Asia [1, 2]. This disease is caused by protozoa of the genus Leishmania and transmitted by the bite of infected sandflies. The World Health Organization estimated 1.3 million new cases annually, divided into 300,000 cases of visceral leishmaniasis and 1 million cases of cutaneous leishmaniasis. [2]. The therapeutic arsenal for the treatment of leishmaniasis is limited and still unsatisfactory. The treatment is not only challenging and long, but also offers a reduced option of drugs, most of which are toxic such as antimonials, amphotericin B, pentamidine and miltefosine $[3,4]$. Considering this problematic context and lack of interest from the pharmaceutical sector, the search for novel drugs is crucial [5]. Based on this aspect, natural products may be considered an interesting source of new molecules for the development of scaffolds for protozoal diseases, including leishmaniasis. Previous studies by our group performed on the $n$-hexane extract from twigs of Nectandra leucantha (Lauraceae) yielded three neolignans with significant antileishmanial and immunomodulatory activity against Leishmania (L.) donovani [6]. Additionally, these related compounds displayed activity against Trypanosoma cruzi [7]. As part of our continuous studies of $N$. leucantha, in the present work, the crude $n$-hexane extract from twigs of this plant displayed activity against promastigote and amastigote forms of $L$. (L.) infantum (death rate of $100 \%$ at $300 \mu \mathrm{g} / \mathrm{mL}$ ). Aiming to characterize its bioactive compounds, the crude extract was subjected to dereplication procedures using HPLC/HRESIMS to enable the identification of six related neolignans (1-6). Since there was no information concerning the potential of these neolignans against amastigote forms of $L$. (L.) infantum, the crude bioactive extract was fractionated using different chromatographic methods to obtain pure 1-6. Antileishmanial activity and cytotoxicity of each isolated compound was evaluated in vitro and the important chemical features related to the antileishmanial activity of these related natural products were determined.

\section{Methods}

\section{General}

${ }^{1} \mathrm{H}$ and ${ }^{13} \mathrm{C}$ NMR spectra were recorded at 300 and $75 \mathrm{MHz}$, respectively, in a Bruker Ultrashield 300 Avance III spectrometer with a QNP $300(5 \mathrm{~mm})$ probe, using $\mathrm{CDCl}_{3}$ (Aldrich) as the solvent and TMS as the internal standard. HRESIMS spectra were recorded on a Bruker MicroTOF-QII using electrospray ionization in the positive mode. Silica gel (Merck, 230-400 mesh) and Sephadex LH-20 (Sigma-Aldrich) were employed for the column chromatography separation, while silica gel 60 $\mathrm{PF}_{254}$ (Merck) was used for analytical thin-layer chromatography (TLC). Eugenol and methyleugenol, purchased from Sigma-Aldrich, were purified by distillation. Miltefosine was also purchased from Sigma-Aldrich. HPLC analysis was performed in a Dionex Ultimate 3000 chromatograph with a UVD-DAD $170 \mathrm{~V}$ as a detector, using a Luna Phenomenex C18 column $(10 \times 250 \mathrm{~mm}$, particle and pore size of $5 \mu \mathrm{m}$ and $175 \AA$, respectively) in the semi-preparative mode or Dionex C18 $(4.6 \times 250 \mathrm{~mm}$, particle and pore size of $5 \mu \mathrm{m}$ and $120 \AA$, respectively) in the analytical mode.

\section{Plant material and preparation of crude extract}

$N$. leucantha twigs were collected from a single specimen at the Atlantic Forest area of São Paulo state, Brazil, in March 2014. A voucher specimen (EM357) has been deposited in the Herbarium of Institute of Biosciences, University of São Paulo, SP, Brazil. Dried $\left(40{ }^{\circ} \mathrm{C}\right.$ at $72 \mathrm{~h}$ ) and powdered twigs ( $220 \mathrm{~g}$ ) of $N$. leucantha were exhaustively extracted using $n$-hexane at room temperature. After concentration under reduced pressure, $7.9 \mathrm{~g}$ of crude $n$-hexane extract was obtained.

\section{HPLC/HRESIMS analysis}

Part of crude $n$-hexane extract from twigs of $N$. leucantha $(5 \mathrm{mg})$ was dissolved in $\mathrm{MeOH}$ and filtered on a C18 Sep-Pak. HPLC/HRESIMS were recorded on an Shimadzu GC-17A (Kyoto, Japan) HPLC system equipped with a DAD detector. Separation of $10 \mathrm{mg} / \mu \mathrm{L}$ of sample was performed using a Dionex column $(4.6 \times$ $250 \mathrm{~mm}$, particle and pore size of $5 \mu \mathrm{m}$ and $120 \AA$, respectively) eluted with a gradient from $\mathrm{MeOH}: \mathrm{H}_{2} \mathrm{O}$ 1:1 (0 min) to $\mathrm{MeOH} 100 \%$ (35 min), flow rate $1.0 \mathrm{~mL} / \mathrm{min}$ and detection at $237 \mathrm{~nm}$. MS detection (positive mode) was obtained on a Bruker micrOTOF-QII (Billerica, MA, USA) coupled to an Apollo ion source set as follows: dry temperature at $180{ }^{\circ} \mathrm{C}$ and voltage at $4.5 \mathrm{kV}$. The mass/charge ratios were detected in scan $(\mathrm{m} / z 100$ $1200 \mathrm{Da})$ and product ion scan $(m / z$ 50-1200 Da) modes.

\section{Extraction and isolation}

Part of $n$-hexane extract from twigs of $N$. leucantha (7 g) was chromatographed over a silica gel column eluted with mixtures of $n$-hexane:EtOAc (1:0, 9:1, 8:2, $7: 3,6: 4,1: 1,3: 7,1: 9$, and $0: 1)$ to yield ten fractions (A J). Fraction C (1528 mg) was composed of compound 1 (99\% of purity). Fraction E (1928 mg) was ressuspended in $\mathrm{MeOH}$ and chromatographed in a Sephadex LH-20 column eluted with $\mathrm{MeOH}$ to obtain five fractions (E1 E5). Fractions E3 (889 mg) and E4 (268 mg) were composed of compound 2 (100\% of purity). Fraction G (1450 mg) was chromatographed over a silica gel column 
eluted with mixtures of $n$-hexane:EtOAc (9:1, 8:2, 7:3, 6:4, 1:1, 3:7, 1:9, and 0:1) to yield eight fractions (G1 G8). Fraction G3 (386 mg) was chromatographed over a silica gel column eluted with mixtures of $n$-hexane:EtOAc $(8: 2,7: 3,1: 1,3: 7,1: 9$, and $0: 1)$ to obtain five fractions $(\mathrm{G} 3 / 1$ - G3/5). Fraction G3/4 (150 mg) was composed of compound 3 (100\% of purity). Fraction G4 (865 mg) was composed of compound 4 (99\% of purity). Fraction H (108 mg) was purified by semi-preparative RP-18 HPLC, eluted with $\mathrm{MeOH}: \mathrm{H}_{2} \mathrm{O} 8: 2$ (flow rate $=2 \mathrm{~mL} / \mathrm{min}, \lambda=237 \mathrm{~nm}$ ) to yield, respectively, compounds 5 (21 $\mathrm{mg}-99 \%$ of purity) and 6 (14 mg - 100\% of purity).

\section{Bioassays}

BALB/c mice and Golden hamsters were supplied by the animal breeding facility at the Adolfo Lutz Institute, São Paulo, Brazil, and maintained in sterilized cages in a controlled environment, receiving water and food ad libitum.

\section{Parasites}

Isolated promastigotes of Leishmania (L.) infantum (MHOM/BR/1972/LD) were maintained in M-199 medium supplemented with $10 \%$ calf serum and $0.25 \%$ hemin at $24{ }^{\circ} \mathrm{C}$. The $L$. (L.) infantum (MHOM/BR/1972/ LD) was maintained in hamsters (Mesocricetus auratus). Amastigotes were harvested from spleens of infected hamsters. The animals were infected with $10^{8}$ amastigotes $(300 \mu \mathrm{L})$ by the i.p. route. At 60 days post-infection, the animals were euthanized, and the spleens analyzed by light microscopy using Giemsa-stained smears. The parasite load was expressed in Leishman-Donovan units (i.e., the number of amastigotes per 1000 nucleated cells $\mathrm{x}$ organ weight [in $\mathrm{g}] \times$ $2 \times 10^{5}$ ). Briefly, the spleen was macerated in a tissue grinder tube containing $5 \mathrm{~mL}$ of phosphate-buffered saline (PBS), whereas the amastigotes were separated by differential centrifugation to obtain a suspension of parasites. The first centrifugation of the spleen suspension (0.8 rpm) was employed to separate the red and white cells (pellet) from the amastigote forms (supernatant). Next, a second centrifugation of the supernatant from the previous step $(2.8 \mathrm{rpm})$ was performed to concentrate the amastigote forms [8].

\section{Mammalian cells}

Peritoneal macrophages were collected from the peritoneal cavity of female BALB/c mice by washing with RPMI-1640 without phenol red, supplemented with $10 \%$ fetal bovine serum. Murine conjunctive cells (NCTC clone L-929, ATCC) were maintained in RPMI-1640 supplemented with $10 \% \mathrm{FBS}$ at $37^{\circ} \mathrm{C}$ in a humidified atmosphere containing $5 \% \mathrm{CO}_{2}[9]$.

\section{Determination of the activity against Leishmania (L.) infantum. - promastigotes}

To determine the antileishmanial activity and the 50\% effective concentration $\left(\mathrm{EC}_{50}\right.$ value) against promastigotes, crude $n$-hexane extract and pure compounds 1-6 were dissolved in DMSO $(30 \mathrm{mg} / \mathrm{mL})$ and diluted with M-199 medium in 96-well microplates. Promastigotes were counted in a Neubauer hemocytometer and seeded at $1 \times 10^{6} /$ well to obtain a final volume of $150 \mu \mathrm{L}$. Controls with DMSO and without drugs were also performed. Miltefosine was dissolved in $\mathrm{H}_{2} \mathrm{O}$ at $30 \mathrm{mg} / \mathrm{mL}$ and used as a standard drug. To determine the antileishmanial potential, crude extract was tested at $300 \mu \mathrm{g} / \mathrm{mL}$ while compounds 1-6 and positive control miltefosine were tested at top concentration $200 \mu \mathrm{g} / \mathrm{mL}$ and were 2 -fold serially diluted into seven concentrations (100, 50, $25,12.5,6.75,3.37$, and $1.69 \mu \mathrm{g} / \mathrm{mL}$ ). Each point was tested in duplicate. The plate was incubated for $48 \mathrm{~h}$ at $24{ }^{\circ} \mathrm{C}$ and the viability of promastigotes was verified by morphology in light microscopy and by the MTT assay [10]. Briefly, MTT $(5 \mu \mathrm{g} / \mathrm{mL})$ was dissolved in PBS, sterilized through $0.22 \mu \mathrm{m}$ membranes and added $\left(20 \mu \mathrm{L} /\right.$ well) for $4 \mathrm{~h}$ at $24{ }^{\circ} \mathrm{C}$. Promastigotes were incubated without compounds and used as viability control. Formazan extraction was performed using 10\% SDS for $18 \mathrm{~h}(80 \mu \mathrm{L} /$ well $)$ at $24{ }^{\circ} \mathrm{C}$ and the optical density (OD) was determined in a Multiskan MS (UNISCIENCE) at $550 \mathrm{~nm}$. One hundred percent (100\%) viability was expressed based on the OD of control promastigotes, after normalization.

\section{Determination of the activity against $L$. (L.) infantum. - intracellular amastigotes}

To determine the $50 \%$ effective concentration $\left(\mathrm{EC}_{50}\right.$ value), mice peritoneal macrophages were collected from the peritoneal cavity of BALB/c mice, then seeded at $1 \times$ $10^{5}$ /well for $24 \mathrm{~h}$ in a 16 -well slide (Nunc - Thermo) at $37{ }^{\circ} \mathrm{C}$. Amastigotes were isolated from spleens of previously infected hamsters, and separated by differential centrifugation [8]. The tissue sample was macerated to break the cell membranes to release all cell contents including the amastigotes. Then the lysate was subjected to two repeated centrifugations $(0.8 \mathrm{rpm}$ followed $2.8 \mathrm{rpm}$ ) where density separation causes a sediment. The supernatant and the pellet were recovered via the first and second centrifugation, respectively. Then the purified amastigotes were added to the macrophages at a ratio of 1:10 (macrophage/amastigotes) for $24 \mathrm{~h}$ at $37^{\circ} \mathrm{C}$. Non-internalized parasites were removed by washing once with medium, whereas tested compounds were incubated with infected macrophages for $96 \mathrm{~h}$. Miltefosine was also used as a standard control drug. Subsequently, the cells were fixed with $\mathrm{MeOH}$, stained with Giemsa and observed through a light microscope. The parasite 
burden was determined by the ratio of infected macrophages versus the mean number of amastigotes per macrophage out of 500 macrophages, i.e., the parasitic index (PI) [11]. Similarly to the assays conducted to promastigote forms, the potential of crude $n$-hexane extract was evaluated at $300 \mu \mathrm{g} / \mathrm{mL}$ while the activities of compounds 1-6 and positive control miltefosine against amastigote forms of $L$. (L.) infantum were determined using a top concentration at $200 \mu \mathrm{g} / \mathrm{mL}$ and were 2 -fold serially diluted into seven concentrations $(100,50,25$, $12.5,6.75,3.37$, and $1.69 \mu \mathrm{g} / \mathrm{mL}$ ). Each point was tested in duplicate.

\section{Determination of the cytotoxicity against mammalian cells}

To determine the $50 \%$ cytotoxic concentration $\left(\mathrm{CC}_{50}\right.$ value), NCTC cells-clone $929\left(6 \times 10^{4}\right.$ cells/well $)$ were seeded at $4 \times 10^{4}$ cells per well in 96-well microplates and incubated with compounds $1-6$ for $48 \mathrm{~h}$ at $37^{\circ} \mathrm{C}$ in a $5 \% \mathrm{CO}_{2}$ incubator using a top concentration at $300 \mu \mathrm{g} / \mathrm{mL}$ and were 2 -fold serially diluted over seven concentrations (150, 75, 37.5, 18.75, 9.37, 4.69 and $2.34 \mu \mathrm{g} / \mathrm{mL}$ ). Each point was tested in duplicate. The selectivity index (SI) was determined using the following ratio: $\mathrm{CC}_{50}$ against macrophages/EC $\mathrm{E}_{50}$ against amastigotes. Cell viability was determined by the MTT assay as described previously [10].

\section{Statistical analysis}

The obtained data represent the mean and standard deviation of duplicate samples from two independent assays. $\mathrm{EC}_{50}$ values were calculated using sigmoid doseresponse curves in the software GraphPad Prism 5.0; the 95\% confidence intervals are included in parentheses. The Mann-Whitney test was used for the significance test ( $P$ value).

\section{Results and discussion}

The antileishmanial potential of $n$-hexane extract from twigs of $N$. leucantha was evaluated against promastigote and amastigote forms of $L$. (L.) infantum; $100 \%$ death of parasites was detected at $300 \mu \mathrm{g} / \mathrm{mL}$. This extract was subjected to the dereplication procedure using HPLC/HRESIMS (Fig. 1), which indicated the occurrence of related neolignans from the quasi-molecular ion peaks at $m / z 349.1423[\mathrm{M}+\mathrm{Na}]^{+}, 363.1585[\mathrm{M}+$ $\mathrm{Na}]^{+}, 365.1237[\mathrm{M}+\mathrm{Na}]^{+}, 379.1506[\mathrm{M}+\mathrm{Na}]^{+}, 327.1589$ $[\mathrm{M}+\mathrm{H}]^{+}$, and $355.1911[\mathrm{M}+\mathrm{H}]^{+}$, corresponding to molecular formulas $\mathrm{C}_{20} \mathrm{H}_{22} \mathrm{O}_{4}(\mathbf{1}), \mathrm{C}_{21} \mathrm{H}_{24} \mathrm{O}_{4}$ (2), $\mathrm{C}_{20} \mathrm{H}_{22} \mathrm{O}_{5}$ (3), $\mathrm{C}_{21} \mathrm{H}_{24} \mathrm{O}_{5}$ (4), $\mathrm{C}_{20} \mathrm{H}_{22} \mathrm{O}_{4}$ (5) and $\mathrm{C}_{22} \mathrm{H}_{26} \mathrm{O}_{4}$ (6). Aiming to obtain bioactive compounds, the crude extract was subjected to several chromatographic steps to yield pure compounds 1-6 which were analyzed by NMR. The ${ }^{1} \mathrm{H}$ NMR spectra of compounds 1-4 displayed a

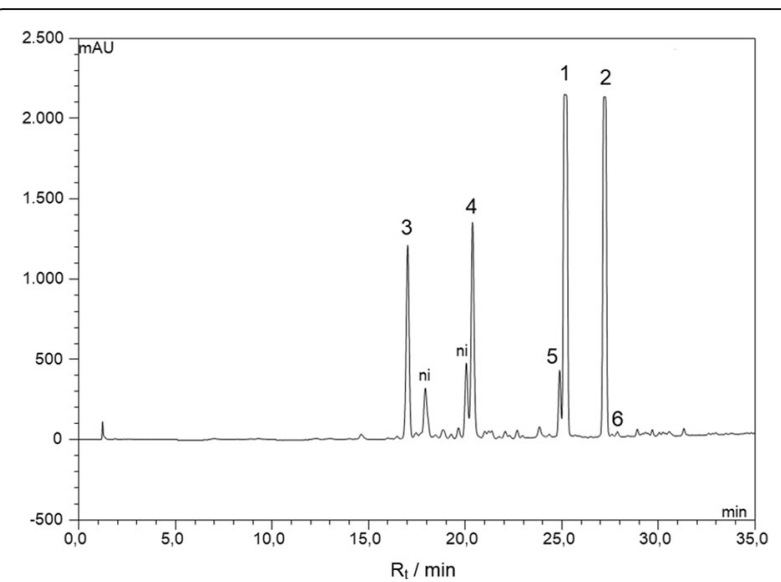

Fig. $1 \mathrm{HPLC} / \mathrm{HRESIMS}$ analysis of crude $\mathrm{n}$-hexane extract from twigs of $\mathrm{N}$. leucantha. Compound $\mathbf{1} \mathrm{m} / \mathrm{z} 349.1423[\mathrm{M}+\mathrm{Na}]^{+}$, compound $2 \mathrm{~m} / \mathrm{z} 363.1585[\mathrm{M}+\mathrm{Na}]^{+}$, compound $\mathbf{3} \mathrm{m} / \mathrm{z} 365.1237[\mathrm{M}+\mathrm{Na}]^{+}$, compound $\mathbf{4} \mathrm{m} / \mathrm{z} 379.1506[\mathrm{M}+\mathrm{Na}]^{+}$, compound $\mathbf{5} \mathrm{m} / \mathrm{z} 327.1589$ $[\mathrm{M}+\mathrm{H}]^{+}$, and compound $6 \mathrm{~m} / \mathrm{z} 355.1911[\mathrm{M}+\mathrm{H}]^{+}$.

ni $=$ non-identified compound

profile of neolignan derivatives attributable to signals of hydrogens from aromatic rings at $\delta 6.90-6.81(\mathrm{~d}, J=$ $\left.8.1 \mathrm{~Hz}, \mathrm{H}-5^{\prime}\right), 6.79$ (d, $\left.J=2.0 \mathrm{~Hz}, \mathrm{H}-2^{\prime}\right), 6.71-6.69$ (dd, $J$ $=8.1$ and $\left.2.0 \mathrm{~Hz}, \mathrm{H}-6^{\prime}\right), 6.70-6.48(J=1.8 \mathrm{~Hz}, \mathrm{H}-2)$ and 6.56-6.27 (d, $J=1.8 \mathrm{~Hz}, \mathrm{H}-6)$, to saturated carbon aliphatic hydrogens at $\delta 3.24-5.04(\mathrm{~d}, J=6.6 \mathrm{~Hz}, \mathrm{H}-7)$ and $3.36-3.39$ (d, $\left.J=6.7 \mathrm{~Hz}, \mathrm{H}-7^{\prime}\right)$ as well as to hydrogens linked to $\mathrm{sp}^{2}$ carbons at $\delta 5.06-5.98\left(\mathrm{~m}, \mathrm{H}-8 / \mathrm{H}-8^{\prime}\right.$ and H-9/H-9'). Additionally, the spectra of compounds 1 and 3 showed two intense singlets at $\delta 3.89(3 \mathrm{H})$ and $3.86(3 \mathrm{H})$ attributable to methoxyl groups at $\mathrm{C}-5$ and C-3'. In the case of compounds 2 and $\mathbf{4}$, two singlets were observed at $\delta 3.87(6 \mathrm{H})$ and $3.83(3 \mathrm{H})$, assigned to methoxyl groups at C-4, C-5 and C-3'. ${ }^{13} \mathrm{C}$ NMR spectra of compounds 1-4 displayed ten signals at range of $\delta$ $105-153$ and two signals at approximately $\delta 144$, which revealed the presence of two aromatic rings linked by an oxygen bond. Additional $\mathrm{sp}^{2}$ carbon atoms at $\delta 116-140$ (C-8/C-8' and C-9/C-9'), associated with the presence of methylene carbon atoms at approximately $\delta 40$ (C-7/ C-7') in $\mathbf{1}$ and $\mathbf{2}$, indicated the presence of two allyl side chains. Otherwise, in the cases of $\mathbf{3}$ and $\mathbf{4}$, signals were observed at approximately $\delta 75.0(\mathrm{CH})$, which were attributed to the carbinolic carbon $\mathrm{C}-7$. The ${ }^{1} \mathrm{H}$ NMR spectra of compounds $\mathbf{5}$ and $\mathbf{6}$ displayed a similar profile of eugenol attributable to the signals attributed to hydrogens of aromatic rings at $\delta 6.69-6.73(\mathrm{~d}, J=2.0 \mathrm{~Hz}, \mathrm{H}-2$ / $\left.\mathrm{H}-2^{\prime}\right)$ and $6.74-6.76\left(\mathrm{~d}, J=2.0 \mathrm{~Hz}, \mathrm{H}-6 / \mathrm{H}-6^{\prime}\right)$, to saturated carbon aliphatic hydrogens at $\delta 3.36(\mathrm{~d}, J=6.7 \mathrm{~Hz}, \mathrm{H}-7$ / $\left.\mathrm{H}-7^{\prime}\right)$, and to hydrogens linked to $\mathrm{sp}^{2}$ carbons at $\delta 5.09$ 5.98 (m, H-8/H-8' and H-9/H-9'). Additionally, intense singlets at $\delta 3.92$ (compound 5) and $\delta 3.63 / 3.88$ (compound 6) were assigned to methoxyl groups. The ${ }^{13} \mathrm{C}$ 
NMR spectra of compounds $\mathbf{5}$ and $\mathbf{6}$ showed nine signals related to the $\mathrm{C}_{6}-\mathrm{C}_{3}$ structure as well as additional peaks attributable to methoxyl groups at $\delta_{\mathrm{C}} 56.1$ to compound 5 and at $\delta_{C} 56.0 / 60.8$ to compound 6 . The pattern related to a tetrasubstituted aromatic ring confirmed the C-C linkage between two aromatic rings. The spectroscopic data of 1-6 were in accordance with those previously reported in the literature $[6,7,12-18]$, allowing the identification of dehydrodieugenol B (1), 1-(8-propenyl)-3-[3'-methoxy-1' -(8-propenyl)phenoxy]-4,5-dimethoxybenzene (2), 1-[(7R)-hydroxy-8-propenyl]-3-[3'-methoxy-1' - (8' -propenyl)-phenoxy]-4-hydroxy-5-methoxybenzene (3), 1[(7R)-hydroxy-8-propenyl]-3-[3'-methoxy-1' -(8' -propeny 1)-phenoxy]-4,5-dimethoxybenzene (4), dihydrodieugenol (5), and dehydrodieugenol dimethyl ether (6) as shown in Fig. 2.

All isolated compounds were evaluated against promastigotes and amastigote forms of $L$. (L.) infantum to determine their $\mathrm{EC}_{50}$ values, followed by comparison of the values obtained for the standard drug (miltefosine). Furthermore, the cytotoxicity values $\left(\mathrm{CC}_{50}\right)$ against NCTC - L929 cells as well as their in vitro selectivity index (SI) were determined. Promastigotes of $L$. (L.) infantum were incubated with compounds 1-6 for $48 \mathrm{~h}$<smiles>[R]Oc1ccc(CC=C)cc1Oc1cc(CC=C)cc(OC)c1Oc1cc(CC=C)cc(-c2cc(CC=C)cc(OC)c2[R2])c1O</smiles>

and the viability was determined by the MTT assay [10, $19,20]$. The obtained results indicated that compounds 4 and 6 were active, displaying $\mathrm{EC}_{50}$ values of $65.4 \mu \mathrm{M}$ (95\% confidence interval of 59.7 to $72.3 \mu \mathrm{M}$ ) and $88.8 \mu \mathrm{M}$ (95\% confidence interval of 76.2 to $103.7 \mu \mathrm{M})$, respectively. When tested against intracellular amastigotes, compounds $\mathbf{2}, \mathbf{4}$ and $\mathbf{6}$ showed activity with $\mathrm{EC}_{50}$ values of $57.9 \mu \mathrm{M}$ (95\% confidence interval of 47.8 to $70.2 \mu \mathrm{M}), 67.7 \mu \mathrm{M}$ (95\% confidence interval of 54.5 to $84.2 \mu \mathrm{M})$ and $13.7 \mu \mathrm{M}$ (95\% confidence interval of 11.7 to $16.0 \mu \mathrm{M})$, respectively. Compounds $\mathbf{1}, \mathbf{3}, \mathbf{5}$ and monomers (eugenol and methyl eugenol) showed no activity against either tested form at the maximum tested concentration $(100 \mu \mathrm{M})$. Miltefosine was used as standard drug with $\mathrm{EC}_{50}$ values of $16.9 \mu \mathrm{M}(95 \%$ C.I. $=11.6$ to $18.6 \mu \mathrm{M})$ against promastigotes and $16.4 \mu \mathrm{M}$ (15.5 to 17.5 $\mu \mathrm{M}$ ) against intracellular amastigotes (Table 1). In the cytotoxicity assay against NCTC cells, compound $\mathbf{5}$ was toxic with a $\mathrm{CC}_{50}$ value of $58.1 \mu \mathrm{M}$, while no toxicity was observed in relation to the other compounds $\left(\mathrm{CC}_{50}>200 \mu \mathrm{M}\right)$. The standard drug miltefosine showed a $\mathrm{CC}_{50}$ value of $122 \mu \mathrm{M}$. Therefore, calculated SI values against amastigote forms were $>3.4,>2.9$ and $>14.6$ for compounds 2,4 and 6 respectively.

It is important to highlight that the efficacy and toxicity of compound $\mathbf{6}$ was similar to miltefosine. Recently, the DNDi (Drugs for Neglected Diseases initiative) defined criteria and proposed cutoff values to qualify the compounds investigated into hit compounds. They include: $\mathrm{EC}_{50}<10 \mu \mathrm{M}$, SI tenfold more active vs.

Table 1 Anti- Leishmania (L.) infantum (promastigote and amastigote forms) and mammalian cytotoxicity (NCTC cells) activities of compounds $\mathbf{1 - 6}$ isolated from Nectandra leucantha and eugenol/methyleugenol

\begin{tabular}{|c|c|c|c|c|}
\hline \multirow[t]{3}{*}{ Compounds } & \multicolumn{2}{|c|}{$\mathrm{EC}_{50}(\mu \mathrm{M}) 95 \% \mathrm{Cl}$} & \multirow{3}{*}{$\begin{array}{l}\mathrm{CC}_{50}(\mu \mathrm{M}) \\
95 \% \mathrm{Cl} \\
\text { NCTC }\end{array}$} & \multirow{3}{*}{$\begin{array}{l}\text { SI } \\
\text { Amastigote }\end{array}$} \\
\hline & \multicolumn{2}{|c|}{ Leishmania (L.) infantum } & & \\
\hline & Amastigote & Promastigote & & \\
\hline 1 & NA & NA & $>200$ & - \\
\hline 2 & $\begin{array}{l}57.9 \\
(47.8-70.2)\end{array}$ & NA & $>200$ & $>3.4$ \\
\hline 3 & NA & NA & $>200$ & - \\
\hline 4 & $\begin{array}{l}67.7 \\
(54.5-84.2)\end{array}$ & $\begin{array}{l}65.4(59.7- \\
72.3)\end{array}$ & $>200$ & $>2.9$ \\
\hline 5 & NA & NA & 58.1 & - \\
\hline 6 & $\begin{array}{l}13.7 \\
(11.7-16.0)\end{array}$ & $\begin{array}{l}88.8 \\
(76.2-103.7)\end{array}$ & $>200$ & $>14.6$ \\
\hline eugenol & NA & NA & $>200$ & - \\
\hline methyleugenol & NA & NA & $>200$ & - \\
\hline miltefosine & $\begin{array}{l}16.9 \\
(11.6-18.6)\end{array}$ & $\begin{array}{l}16.4 \\
(15.5-17.5)\end{array}$ & 122.0 & 7.2 \\
\hline
\end{tabular}

$\mathrm{EC}_{50} 50 \%$ effective concentration, $\mathrm{CC}_{50} 50 \%$ cytotoxic concentration, $\mathrm{SI}$ selectivity index, NA Not Active 95\%, Cl 95\% confidence interval 
mammalian cell line, no structural alerts (metabolism, stability and reactivity), chemical tractability (acceptable synthetic pathway for compound and/or analogues $(<8$ steps) etc. [21]. Compound 6 conforms with many of these criteria and could be eventually be addressed to the hit-to-lead optimization phase. Although the activity of compound 6 against promastigote forms of $L$. (L.) amazonensis has previously been reported in the literature [18], the present work described the activity of compound 6 against intracellular amastigotes of $L$. (L.) infantum, the clinically relevant form of Leishmania, which results in a fatal visceral disease if untreated [22].

Comparing the data shown in Table 1 with the chemical structures of compounds 1-6 and eugenol/methyleugenol, it was possible to suggest that coupling of monomers is a crucial step to obtain antileishmanial compounds since only dimeric derivatives (neolignans) displayed activity. By analyzing the activity data of closely related compounds $\mathbf{1 - 4}$, it was revealed that compounds $\mathbf{2}$ and $\mathbf{4}$ were active, suggesting that the presence of a methoxyl group at C-4 constitutes an important chemical feature to enhance the antiparasitic potential. As observed, neolignans containing free hydroxyl group at C-4 (1 and 3) were inactive, suggesting that polarity directly affects the antileishmanial potential of related compounds. Similarly, the presence of an additional hydroxyl group in the allyl side chain, as observed in compounds $\mathbf{2}$ and $\mathbf{4}$, causes a reduction in the potential. Comparing the activity of neolignans $\mathbf{5}$ and $\mathbf{6}$, it was observed that the presence of additional methoxyl group also enhances the antileishmanial activity as displayed by compounds 1-4, suggesting that the presence of this substituent is crucial to antileishmanial activity of these related neolignans. Finally, as previously reported [13], in silico analysis of compounds 1-6 indicated that compound $\mathbf{6}$ was predicted as a non pan-assay interference compound (PAINS) and displayed some favorable in silico ADMET properties - non-mutagenic, non-carcinogenic, non-genotoxic, weak hERG blockers, with an acceptable volume of distribution $(1.66-3.32 \mathrm{~L} / \mathrm{kg})$, and low rodent oral toxicity $\left(\mathrm{LD}_{50}=810-2200 \mathrm{mg} / \mathrm{kg}\right)$.

\section{Acknowledgements}

We thank CNPq for the scientific research award to JHGL and AGT, and CAPES for fellowships to SSG and TACS. We also thank Dr. Lauren Webster from University of Dundee for suggestions in the preparation of this manuscript.

\footnotetext{
Funding

This work was funded by grants and fellowships provided by Fundação de Amparo a Pesquisa do Estado de São Paulo (FAPESP - projects 2018/078851 and 2015/23403-9). Moreover, this publication was supported by the Coordination for the Improvement of Higher Education Personnel (CAPES) through Programa Editoração CAPES (edital n. 13/2016, auxílio n. 0722/2017, processo n.88881.142062/2017-01) and by the National Council for Scientific and Technological Development (CNPq) through Programa Editorial CNPq/ CAPES 498 (chamada n. 26/2017, proc. n. 440954/2017-7).
}

\section{Author's contributions}

SSG, TACS, FFS, SBC, EU, and PSM performed the research and analyzed data. SSG, FFS, EU, and PSM performed NMR and MS analysis. TACS, AGT and JHGL wrote the manuscript. AGT and JHGL designed the study. All authors read and approved the final manuscript.

\section{Ethics approval}

Animal procedures were performed with the approval of the Research Ethics Commission (CEUA 02/2011), in agreement with the Guide for the Care and Use of Laboratory Animals from the National Academy of Sciences.

\section{Consent for publication}

Not applicable.

\section{Competing interests}

The authors declare that they have no competing interests.

\section{Publisher's Note}

Springer Nature remains neutral with regard to jurisdictional claims in published maps and institutional affiliations.

\section{Author details}

${ }^{1}$ Center of Natural Sciences and Humanities, Federal University of ABC (UFBC), Avenida dos Estados 5001, Santo Andre, SP 09210-580, Brazil. ${ }^{2}$ Biotechnology and Innovation in Health Postgraduate Program, Anhanguera University of São Paulo, São Paulo, SP, Brazil. ${ }^{3}$ Institute Environmental, Chemical and Pharmaceutical Sciences, Federal University of São Paulo (UNIFESP), Diadema, SP, Brazil. ${ }^{4}$ Center for Parasitology and Mycology, Instituto Adolfo Lutz, São Paulo, SP, Brazil.

Received: 12 April 2018 Accepted: 17 September 2018

Published online: 27 September 2018

\section{References}

1. World Health Organization: Neglected diseases. http://www.who.int/neglected_ diseases/diseases/en/ (2016).

2. World Health Organization: Leishmaniasis. http://www.who.int/leishmaniasis/ en/ (2016).

3. Sundar S, Chakravarty J. An update on pharmacotherapy for leishmaniasis. Expert Opin Pharmacother. 2015;16(2):237-52.

4. Menezes JPB, Guedes CES, Petersen ALOA, Fraga DBM, Veras PST. Advances in development of new treatment for leishmaniasis. BioMed Res Int. 2015;ID 815023. https://www.hindawi.com/journals/bmri/2015/815023/.

5. Moore EM, Lockwood DN. Treatment of visceral leishmaniasis. J Glob Infect Dis. 2010;2(2):151-8.

6. da Costa-Silva TA, Grecco SS, de Sousa FS, Lago JH, Martins EG, Terrazas CA, et al. Immunomodulatory and antileishmanial activity of phenylpropanoid dimers isolated from Nectandra leucantha. J Nat Prod. 2015;78(4):653-7.

7. Grecco SS, Costa-Silva TA, Jerz G, de Sousa FS, Londero VS, Galuppo MK, et al. Neolignans from leaves of Nectandra leucantha (Lauraceae) display in vitro antitrypanosomal activity via plasma membrane and mitochondrial damages. Chem Biol Interact. 2017;277:55-61.

8. Stauber LA, Franchino EM, Grun J. An eight-day method or screening compounds against Leishmania donovani in the Golden hamster. J Protozool. 1958:5(4):269-73.

9. Corrêa DS, Tempone AG, Reimão JQ, Taniwaki NN, Romoff P, Fávero OA, et al. Anti-leishmanial and anti-trypanosomal potential of polygodial isolated from stem barks of Drimys brasiliensis Miers (Winteraceae). Parasitol Res. 2011;109(1):231-6.

10. Tada H, Shiho O, Kuroshima K, Koyama M, Tsukamoto K. An improved colorimetric assay for interleukin 2. J Immunol Methods. 1986;93(2):157-65.

11. Yardley V, Gamarro F, Croft SL. Antileishmanial and antitrypanosomal activities of the 8-aminoquinoline tafenoquine. Antimicrob Agents Chemother. 2010;54(12):5356-8.

12. de Sousa FS, Grecco SS, Girola N, Azevedo RA, Figueiredo CR, Lago JHG. Neolignans isolated from Nectandra leucantha induce apoptosis in melanoma cells by disturbance in mitochondrial integrity and redox homeostasis. Phytochemistry 2017;140:108-117.

13. Grecco SS, Costa-Silva TA, Jerz G, de Sousa FS, Alves Conserva GA, Mesquita $\mathrm{JT}$, et al. Antitrypanosomal activity and evaluation of the mechanism of action of dehydrodieugenol isolated from Nectandra leucantha (Lauraceae) 
and its methylated derivative against Trypanosoma cruzi. Phytomedicine. 2017;24:62-7.

14. Karlsen $M$, Liu H, Berg T, Johansen JE, Hoff BH. Synthesis of $\left[{ }^{13} \mathrm{C}_{6}\right]$-labelled phenethylamine derivatives for drug quantification in biological samples. J Labelled Comp Radiopharm. 2014;57(5):378-87.

15. Suarez $\mathrm{M}$, Bonilla J, AMP d D, Achenbach H. Dehydrodieugenols from Nectandra polita. Phytochemistry. 1983;22(2):609-10.

16. Diaz AMP, Gottlieb HE, Gottlieb OR. Dehydrodieugenols from Ocotea cymbarum. Phytochemistry. 1980;19(4):681-2.

17. Dias AF. An improved high yield synthesis of dehydrodieugenol. Phytochemistry. 1988;27(9):3008-9.

18. Rodrigues LC, Barbosa-Filho JM, de Oliveira MR, Do Nascimento Néris PL, Borges FV, Mioso R. Synthesis and antileishmanial activity of natural dehydrodieugenol and its mono- and dimethyl ethers. Chem Biodivers. 2016;13(7):870-4.

19. Lane JE, Ribeiro-Rodrigues R, Suarez CC, Bogitsh BJ, Jones MM, Singh PK, et al. In vitro trypanocidal activity of tetraethylthiuram disulfide and sodium diethylamine-N-carbodithioate on Trypanosoma cruzi. Am J Trop Med Hyg. 1996;55(3):263-6

20. Tempone AG, Pimenta DC, Lebrun I, Sartorelli P, Taniwaki NN, de Andrade-Jr $H R$, et al. Antileishmanial and antitrypanosomal activity of bufadienolides isolated from the toad Rhinella jimi parotoid macrogland secretion. Toxicon. 2008;52(1):13-21.

21. Don R, loset JR. Screening strategies to identify new chemical diversity for drug development to treat kinetoplastid infections. Parasitology. 2014; 141(1):140-6.

22. Desjeux P. Leishmaniasis: current situation and new perspectives. Comp Immunol Microbiol Infect Dis. 2004;27(5):305-18

Ready to submit your research? Choose BMC and benefit from:

- fast, convenient online submission

- thorough peer review by experienced researchers in your field

- rapid publication on acceptance

- support for research data, including large and complex data types

- gold Open Access which fosters wider collaboration and increased citations

- maximum visibility for your research: over $100 \mathrm{M}$ website views per year

At $\mathrm{BMC}$, research is always in progress.

Learn more biomedcentral.com/submissions 